\title{
Improving the energy efficiency of church buildings
}

\author{
Aleksandra Repelewicz ${ }^{1}$
}

\section{ABSTRACT:}

The implementation of thermal renovation of residential and public buildings is becoming more and more popular. The need to save energy and reduce the energy demand of buildings is becoming a civic duty. Consequently, sacred buildings should also be adapted to the requirements of modern times. Due to the specific use of these facilities and their mostly large cubature, administrators rarely decide to take such measures. Examples of thermomodernization activities in church buildings can be invaluable as they are an example for administrators of other buildings of this type. The paper presents the following case study: A comprehensive thermal renovation of a church building in Rzerzęczyce.

\section{KEYWORDS:}

church buildings; thermal renovation; sacral architecture

\section{Introduction}

For years, heating church interiors has been a big problem for the administrators of these buildings. In buildings with a large cubature, such as churches, it is difficult to obtain thermal comfort. Moreover, historically churches have not been heated for centuries. In the 20th century, with the increase in living standards and the increase in the requirements of the users of sacred buildings, heating systems have started appearing in churches. Unfortunately, the lack of experience and the specific use of buildings resulted in unsatisfactory performance of the utilized heat sources. A typical church is used quite briefly, during services, on weekdays and occasionally on holidays. The number of people at services varies. The schedule of using the church is specific. The thermal comfort criteria applies only to short periods of time and can change on a weekly basis. Between those periods there are less stringent, but also important requirements.

The paper presents the issues of ecological and economic heating of a church interior, using the example of the parish church building in Rzrzęczyce in the deanery of Kłomnice, the Radomsko region of the Częstochowa Diocese. The town is located in the Silesian Voivodeship in the commune of Kłomnice.

\section{The history of construction of the church in Rzerzęczyce}

The first chapel in Rzerzęczyce was built in 1948. The parish was established there by Bishop Stefan Bareła in 1969. That same year a parish priest, B. Panek, began efforts to obtain permission for the expansion of the existing chapel according to the design of arch. Szmerdt. The work started the following year. It was completed thanks to a new parish priest E. Wieczorek and the great commitment and generosity of the parishioners. The church was erected with

1 Czestochowa University of Technology, Faculty of Civil Engineering, ul. Akademicka 3, 42-218 Częstochowa, e-mail: aleksandra.repelewicz@pcz.pl, orcid id: 0000-0003-3578-7547 
economic help and a large contribution of social work from the local population. The church was consecrated in 1972 by Bishop S. Bareła. Thanks to the efforts of the following parish priest Ireneusz Trzebski, a new gable roof was built (previously it has been roofed with roofing felt). In the following years, the façades of the building and the sidewalk around the church were built. The original design of the church has not survived. In the archives, there is only the modernization project from 1992, by L. Pyrkosz, including the replacement of the ceiling and roof and the addition of the third part of the church. Until 2020, the church was unheated and had only an electrical and lightning protection system. In 2020, on the initiative of the parish priest R. Pyzik, a major renovation was carried out, combined with a thermomodernization of the building: insulation of the walls, painting the roof covering, renovation of the interior with replacement of windows and installation of underfloor heating (which was connected with the implementation of a new floor and the use of ecological heating sources).

The church building is a one-story building without a basement. The usable area of the church is $158 \mathrm{~m}^{2}$. The rooms include the nave with the presbytery, sacristy, porch and choir. The floor plan of the church is in the shape of a cross (Fig. 1). The rectangular nave is covered with a gable roof. The height of the main nave is $6.4 \mathrm{~m}$. The sacristy, chancel and porch are also rectangular- shaped, covered with gable roofs with the same slope as the roof over the main body. All the above-mentioned rooms are lower than the height of the nave of the church.

External walls of the nave and sacristy are made of slag blocks and bricks. The porch (added in 1992) is made of MAX ceramic blocks and perforated bricks. The internal walls are made of aerated concrete blocks. Above the building, there is a wooden roof truss, and the roof is covered with a trapezoidal galvanized sheet $[1,2]$.
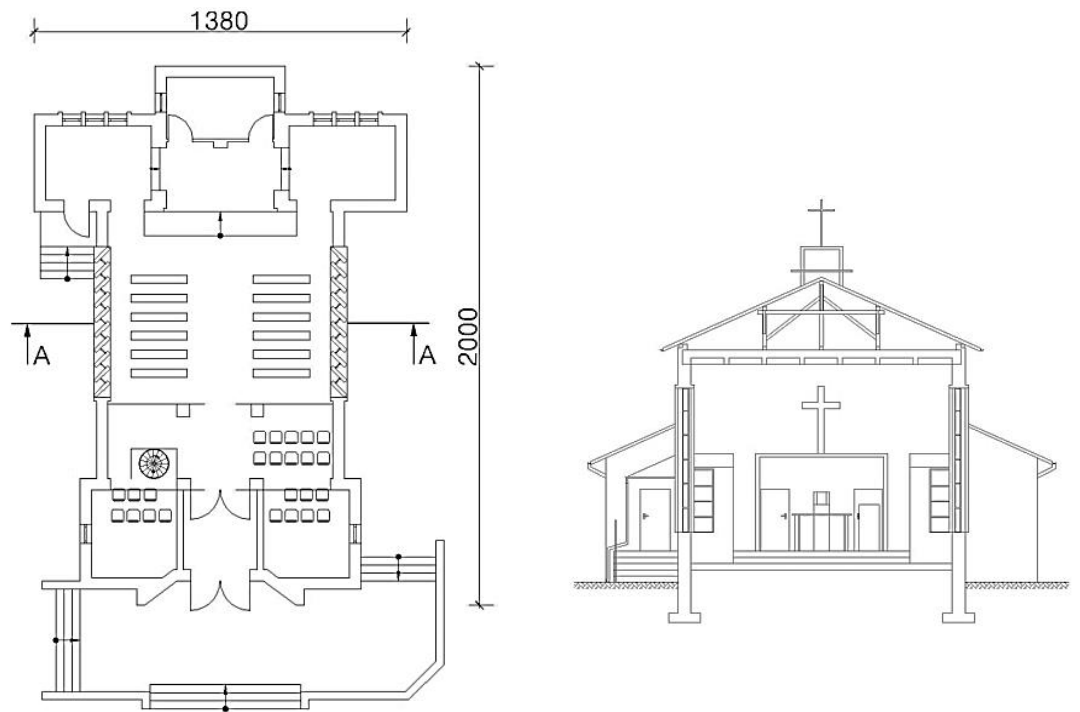

Fig. 1. Floor plan and vertical section A-A of the church in Rzerzęczyce

\section{The extent of the church building's thermomodernization}

Underfloor heating was used in the previously unheated interior of the church. This system is an example of heating widely recognized as environmentally friendly and energy-saving. Water and air underfloor heating systems can work with all energy sources, but they work most effectively with low-temperature heat sources: condensing boiler, heat pump and solar installation. Solar collectors can be supportive, but their efficiency is too low to be the only source of heat for the installation (Fig. 2). However, they can reduce heating costs with a different primary source of energy. 
The heat pump is a device that performs most efficiently when there is the smallest possible temperature difference between the lower source (ground, air, water from a natural reservoir) and the upper source (e.g. heating circuit). Underfloor heating is a low-temperature heating system, thanks to a much more effective transfer of heat than other types of radiators. This is due to the large heating surface - the entire floor, which gives off heat through both radiation and convection. This predisposes this heating system to the most effective cooperation with a heat pump (Fig. 3). In heating systems with a heat pump and underfloor heating, the seasonal coefficient of performance (SOP) is approximately $50 \%$ higher than in a system with a heat pump and radiators. Thus, the annual heating costs of the church building may be $1 / 3$ lower in this case. Maintaining a lower water temperature translates directly into lower heating costs. The lower temperature also makes the air movement less intense. Increasing the temperature of the floor increases the intensity of dust lifting.

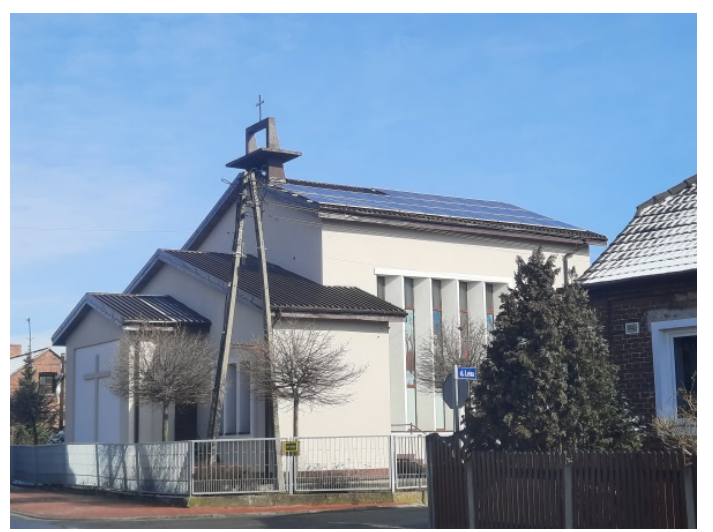

Fig. 2. A view of the church in Rzerzęczyce, photovoltaic panels can be seen on the southern roof slope

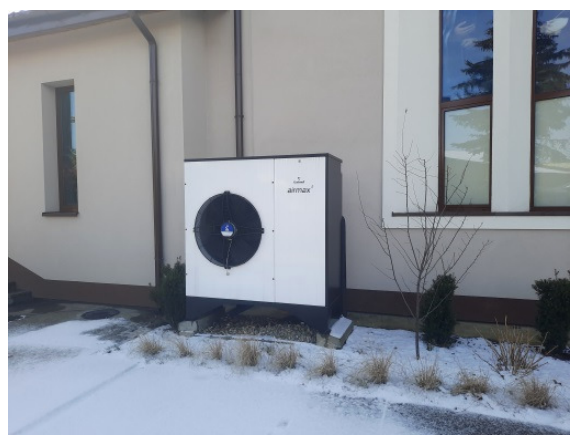

Fig. 3. Heat pump next to the northern wall of the church in Rzerzęczyce

Underfloor heating is a reliable, hygienic solution and does not disturb the aesthetics of the church interior. The floor dries very quickly, which is of great importance when the faithful walk in with wet shoes in unfavorable weather. This reduces the risk of fungus and bacteria growth.

The advantage of this type of heating is even heat dissipation at the floor level. When used, the people using the church are comfortable: warm on the legs, cool at head level. It is the most favorable system in terms of human physiology. Underfloor heating provides a more favorable temperature distribution ensuring a feeling of thermal comfort is achieved at a lower temperature (the perceived temperature is on average 2 to 4 degrees higher compared to traditional heating). Reducing the room temperature translates into additional savings on heating (it can be assumed that lowering the temperature by one degree brings energy savings of about $6 \%$ ). At a lower air temperature in the room, the heat demand for heating the ventilation air decreases. 
The heat losses of the supply lines are small due to the low temperature of the heating medium. Thus, this type of heating is energy efficient, consuming less energy to produce comparable thermal comfort than traditional radiator heating.

The church in Rzerzęczyce uses an air-to-water heat pump with a heating capacity of $26.01 \mathrm{~kW}$ and an electrical power consumption of $5.64 \mathrm{~kW}$. The pump was located at the side wall of the building (Fig. 3). In addition, photovoltaic panels (Fig. 2) were installed on the entire southern slope of the roof, which powers the floor heating system and the electrical installation of the facility. The power of the photovoltaic installation on the church building is $7.28 \mathrm{~kW}$. There are also pellet stoves in the boiler room, which can be used in the event of a particularly high load on the heating system. It should be noted that in the first year of use, during heating season $2020 / 2021$, there was no need to start up these furnaces and despite the frosty weather, the power of the heat pump and photovoltaic panels was sufficient to heat the church. The church building in Rzerzeczyce is suitable for the use of underfloor heating, because the interior has a relatively low height and there is no problem with the presence of warm air masses being that much higher than the zone where people are [3].

\section{Summary}

The church in Rzerzęczyce is an example of a thorough thermal modernization of a sacred building. The walls were insulated, windows were replaced and a floor heating system powered by a heat pump supported by solar collectors was used. This project was completed in 2020 , therefore the economic effects are not known yet. On the other hand, the social effects are very positive - the change is huge for the local community. Now, the previously unheated interior of the church has been heated, which significantly increases the comfort of those using the church building. Nowadays, the faithful want to participate in the services in conditions of thermal comfort. Heating costs will be low due to the use of ecological heat sources. At the same time, these heat sources are perfectly suited to the underfloor heating system.

Sacred buildings are often unheated or heated imperfectly and often at a cost. Certainly, large and very large buildings require other solutions in the field of interior heating, but the presented church building in Rzerzęczyce can be an excellent example of effective thermal modernization for relatively small sacred buildings. It is very likely that this positive example will inspire other parish communities to pro-ecological activities and that thermal modernization will include more church buildings.

\section{References}

[1] Leszek Pyrkosz, Projekt techniczny, modernizacja kościoła pw. św. Floriana w Rzerzęczycach, Częstochowa 1992.

[2] Dziennik budowy Nr 1, modernizacja Kościoła pw. św. Floriana w Rzerzęczycach, 1992.

[3] Aleksandra Olas, Projekt budowlany. Instalacje sanitarne, 2019.

\section{Poprawa efektywności energetycznej budynków kościołów}

\section{STRESZCZENIE:}

Przeprowadzanie termorenowacji budynków mieszkalnych i użyteczności publicznej staje się coraz bardzie popularne. Konieczność oszczędzania energii i obniżenie zapotrzebowania budynków na energię staje się wymogiem cywilizacyjnym. Także obiekty sakralne powinny być dostosowywane do wymogów współczesności. Ze względu na specyfikę użytkowania tych obiektów oraz ich zazwyczaj dużą kubaturę administratorzy dość rzadko decydują się na takie działania. Tym cenniejsze są przykłady podejmowania działań termomodernizacyjnych w budynkach kościołów, które mogą być przykładem dla administratorów innych kościołów. W referacie przedstawiono studium przypadku: termorenowację budynku kościoła w Rzerzęczycach.

SŁOWA KLUCZOWE:

budynki kościołów; termomodernizacja; architektura sakralna 